\title{
Verbal Groups of Telic Action in Albanian Language
}

\author{
Prof. Gjilda Alimhilli Prendushi \\ Albanian Language and Literature \\ University of Bari "Aldo Moro" (Italy)
}

\begin{abstract}
In this article I introduce and analyze the syntactic behaviour (compatibility and restrictions) of achievement and accomplishment verbs in standard Albanian, according to Aktionsart ${ }^{1}$. The Aktionsart is a system of classification of verbs into verbal classes morphologically distinct from each other, in which at the basic meaning of the verb are added different values of space, quality, etc. The accomplishments and achievements in Albanian have comparable action meaning and syntactic behavior, such as to justify their inclusion in the class of telic verbs. A telic verb is that one which presents an action or event as being completed in some manner. On the other hand, these two subclasses of telics are also characterized on the basis of a series of distinctive elements that lead us to lay a certain distinction between them. An accomplishment verb is a form that expresses that something or someone has undergone a change in state as the result of the completion of an event. On the other side an achievement verbs express an instant action that changes the state of the subject. By using the categories and procedures of textual linguistics I focus on the semantic and syntactic features of some groups of verbs.
\end{abstract}

Keywords: Verbal groups of telic action in Albanian language

\section{Introduction}

\section{Verbal groups of punctual action}

The verbs of this class indicate sudden action, very fast, in the moment of its conclusion. They are completely telic. In this class, in the Albanian language, are included those verbs called punctuals such as: bie 'fall', çel 'open', dal 'leave', flak 'throw away', godas 'hit', këpus 'knock off', kyç 'seal' , ngordh 'die', pushkatoj 'shot', qëlloj 'hit', vetëtin 'flash', vdes 'die ', shkreh 'shoot', zgjohem 'wake up', gjej 'find', refuzoj 'refuse ', çuditem 'wonder', etc:

[1] E gjeti shtëpinë/ Vdiq nga sëmundja/ Çeli sytë/ E flaku në tokë/ etj.

(He/She) found the house / (He/She) died from the disease / (He/She) opened the eyes / (He/She) thrown down/ etc.

There are included here even the terminative ${ }^{2}$ verbs like: mbaroj 'finish', pushoj 'stop', përfundoj 'conclude', perëndoj 'gone down', sos 'finish', and so on.

[2] Mbaroi së foluri/ Pushuan së mbledhuri të gjithë materialet/ E sosi bisedën.

(He/She) finished speaking / (He/She) stopped collecting all the things / (He/She) finished the chat.

In Albanian language we also have specific means for the formation of words which express the idea of a timely action, such as prefixes për-, $d(\ddot{e})-, k(a)-$, rrë-, sh-, respectively illustrated in the examples: përlaj 'grab', përmend 'revive', përpij 'suck', përpjek 'beat', përplas 'slam', përvëloj 'glow ' etc .; dëboj 'expel', dështoj 'abort', etc .; kapërcej 'cross', kapërdij 'swallow', kapërthej 'possessed', kaploj 'surprise', etc .; rrëmbej 'grab', rrëzoj 'destroy', etc .; shfrej 'rave', shkreh 'triggers/burst', shlyej 'expiate', shkrep 'flash', etc .:

\footnotetext{
${ }^{1}$ For the characteristics of the telic verbal action in Albanian, see Alimhili Prendushi (2001: 371-395, 2009: 37-58 \& 2013: 163-166).

2 In this case, and in some others later, it is kept the term "terminative" used by previous authors. In our work, these verbs are included in the aspectual group.
} 
[3] E përlau pjatën/ Më përvëloi gojën.

(He/She) devoured the plate / (It) glowed the mouth.

[4] E dështoi foshnjën/ Dëboji qentë.

(She) aborted the baby / Expel the dogs.

[5] Dallga e kapërdiu barkën / E kapërtheu tmerri/ Më kaploi gjumi.

The tide swallowed the boat / Possessed from the dread /The sleep surprised me.

[6] la rrëzoi tërmeti shtëpinë/ Skifteri rrëmbeu një pulë.

The earthquake destroed his house / The hawk grabbed a chicken.

[7] Qau e shfreul Shkreh pushkën1.

(He/She) cried and raved / Trigger the gun.

The idea of punctuality is also expressed by other special syntactic constructions, such një të kthyer, me të kthyer which in English can be translated roughly as 'back / just back'2:

[8] Me të zbritur nga autobuzi, ato u ndanë.

Went down from the bus, they were separated.

[9] Një t'u kthyer dhe shkoi tek ajo.

Just turned back and went to her.

In these examples we see that it accentuates the fast switch, momentary, of the action to another action. This construction gives punctual value even in those cases where we have to do with verbs whose semantics it is not as this:

[10] Me të dëgjuar thirrjen, u ngrit.

On hearing the call, get up.

Even the cases of the use of different onomatopoeia are correlated with the expression of punctual value of the action:

[11] la tha bam.

(He/She) said it bam.

To emphasize the idea of punctual action, are used a number of adverbial expressions, as befas 'abruptly', menjëherë 'immediately', papritur 'suddenly', në çast 'instantly', aty për aty 'on the spot', pa pandehur 'unexpectedly', shpejt 'quickly', shpejt e shpejt 'quickly and quickly', sa çel e mbyll sytë 'in a jiffy', etc.

[12] Hyri befas/ Aty për aty harron/ Erdhi papriturl Shpejt e shpejt e mbaroi punën.

(He/She) come in abruptly / On the spot forgets / (He/She) come suddenly / Quickly and quickly finished the job.

\footnotetext{
${ }^{1}$ In Albanian language the present and the imperfect are realized through:

1. imperfective indeterminate forms (temporal-aspectual imperfective forms), such as: punoj-punoja.

2. perfective determinate forms (temporal-aspectual perfective forms) made with constructions:

a. particle $p o+$ the present of indeterminate imperfective ( $p o$ punoj)

particle $p o+$ the imperfect of indeterminate imperfective (po punoja)

b. jam + gerund. (jam duke punuar)

jam in imperfect of indeterminate imperfective isha + gerund. (isha duke punuar)

2 For the constructions of this type and for the others as in the example [11], see Floqi (1958: 113-116).
} 


\section{Verbal groups of resultative action}

The appropriate expression of resultative verbal action is realized through syntactic tools. Taken separately, these verbs do not belong to the class of durative verbs, but to another class, as will be shown later.

The groups of words of the type mbarova së foluri 'I finished speaking', zemra i pushoi së rrahuri 'His heart stopped beating', vajza përfundoi së shkruari ' the girl finished to write' etc. have a clear phraseology character. In these groups of words as the first element we find a terminative verb (mainly mbaroj 'finish', pushoj 'stop', përfundoj 'conclude/finish'); However, it is the second element that plays the main role in the general meaning of the word group, while the first is used more as a verb with aspectual value capable of expressing the conclusion of the action expressed by the second term:

- mbaroj 'finish' (pushoj 'stop', sos 'finish', përfundoj 'conclude/finish') (usually in the simple past, and less in the other tenses of indicative and even less in the present tense of conjunctive) + a neutre noun in ablative, expressing the ending of the action.

Indicative form

[1] Sapo mbarova së lexuari librin (simple past) / Kur mbaron së ngrëni...(present tense) / ... pushonte së menduari për të (imperfect) / Vetëm ajo ka mbaruar së shkruari (perfect) / Ai kishte mbaruar së piri kafenë ( plusperfect)..

I just finished reading the book / When you finish eating ... / ... stop thinking about him/her/it / Only she has finished writing / He had finished drinking the coffee

Conjunctive form

[2] Duhet të pushojë së shkruari (present tens) /... të kishte mbaruar së marruri me ta (plusperfect).

Should cease writing / ... he have finished dealing with them.

The following buildings, preceded from negative particle $s$ ' or nuk 'not', assume continuous-durative value:

Indicative form

[3] Plaku s'pushon së shari (present tense) / Ai nuk pushonte së harxhuari (imperfect); Gruaja bërtiste dhe nuk pushonte duke sharë (the corresponding verb rarely is presented in gerund)/ Duhet ta dini se s'kam pushuar së menduari për ju (perfect).

The elder don't cease swearing / He couldn't stop spending/ The woman cried and couldn't stop swearing / You should know that I haven't stopped thinking about you.

In addition to the aforementioned groups of words with objective relationships and with terminative value, we also find those with causal relationships of the type $u$ lodha së foluri 'I got tired of talking', expressing the value of action intensity - the first verb is used to express the intensity of the action expressed by the second member - such as $u$ lodha së foluri 'I got tired of talking', plasa së qari 'I burst of tears', u ngjira së thirruri 'I hoarsen's calling' in the sense of: fola aq shumë (sa u lodha) 'I talked so much (as I got tired)', qava aq shumë (sa plasa) 'I cried so much (as I burst)', thirra aq shumë (sa u ngjira) 'I called so much (as I hoarsened)'. It must be emphasized here that, in addition to the intensity value of action, it is undeniable the resultative value of these buildings:

- lodhem 'tire' (plas 'burst', këputem 'fatigue', tire', mekem 'weakening', ngjirem 'hoarsened') + a neutre noun in ablative, which expresses the ending of the action.

Indicative form

[4] Lodhem së foluri me të (present tense)/ Kur u lodh së qari ... (simple past)/ Është lodhur së vajturi çdo verë (perfect)/ Vajza shkulet së qeshuri (present tense)/ Italianët shkuleshin së qeshuri (imperfect)/ Prandaj u shkulën së qeshuri (simple past)/ Ajo plasi së qari tërë ditën (simple past).

\footnotetext{
${ }^{1}$ For these verbal groups it is spoken in the work of Demiraj (1986: 404-405); nella Gramatika e gjuhës shqipe II (1997: 187), but more widely they are discussed in the work of Dhrimo (1996: 260-265; 2008: 332-333 \& 406-410).
} 
Tired talking with him/her; When got tired of crying .../ Tired of going each summer/ The girl erupt laughing/ The italians erupted laughing/ Therefore erupted laughing/ She broke out crying all day

Among the elements of these groups of words can be inserted any other member of the sentence. The close functional and significantive correlation between the two members of the groups of words, of the type in question, means that in the sentence they act as a single predicative member - the first member mainly plays the role of a semi-auxiliary verb. As a result, the complementary members, placed after the participal noun in undetermined ablative, essentially do not belong only to the second member but to the whole group of words, and therefore the terminative value is expressed by the entire group of words and not by his individual elements.

In addition to the group of words analyzed above, we also have other types where occur the repetition of the same verb in the simple past:

- verb + conjunction sa 'how much' + verb

[5] Punuan sa punuan, pastaj zunë të bisedojnë / Ai jetoi sa jetoi në shtëpinë tonë .../ Qeshi sa qeshi dhe iku .

Worked as worked, then began to talk / He lived as he lived in our house ... / Laughed as laughed and ran away.

- verb + conjunction $e$ 'and' or indefinite pronoun ç' 'that' + verb

[6] Dha e dha dhe vendosi të heqë dorë.

Gave and gave and decided to give up.

[7] Pashë ç'pashë dhe ika / Ai bëri ç'bëri dhe iku.

I saw what I saw and left / He does what he does and resign.

The constructions of the type dha e dha 'gave and gave', pa ç'pa 'saw and saw' Beri ç'bëri 'does what he does' are equivalent to u përpoq e u përpoq (u përpoq sa u përpoq) dhe ... 'tried and tried (he attempted what he attempted) and ... '

The examples in [5] indicate that after a certain continuation the action ends, while the cases in [6] and [7] indicate that at the end it is stopped with the intensive attempts and has started a new action.

To express the conclusion of the action are also used phraseolgycal groups with the coordination of synonyms verbs in the simple past, which are joined by the coordinative $e$ :

- verb + conjunction $e(d h e)$ 'and' + verb

[8] Rinia e saj shkoi e vajti.

The youth went and went.

The same value also presents the expression mori fund 'ended':

[9] Mori fund përgjithmonë.

\section{Ended forever.}

Until now we have presented and analyzed verbal groups that indicate the risultative verbal action. Verbs that take part in these constructions, as we have seen, generally occur in the simple past. In Albanian, it is true that the two forms, imperfectaorist, provide the aspectual presentation of the action (in continuation, in summary or completed, respectively), but the form of simple past not always specifies and precise whether the conclusion of action has also reached the goal, the ultimate goal. The considered telic verbs are characterized by the ending point and the actions from them indicated necessarily lead to a result, in contrast to non-telic verbs. The distinction between these two groups of verbs does not belong to the formal structure of Albanian and is not expressed by any particular form, so the Albanian use other means which belong to verbal actions. The risultative verbal action in Albanian is accomplished through verbal groups (just discussed) and verbal syntagme (durative verbs in the simple past + lexical-grammatical means - where it is possible the realization of their meaning -). 
In relation to this last point, the verbs ha 'eat', punoj 'work', laj 'wash', lexoj 'read', etc. in simple past alone give no indication with respect to whether we are dealing with the risultative verbal action - telic, or continuative - non-telic. These semantic aspectual colors do not occur only through this lexical enter of the verb, but through the whole predicate requirements ${ }^{1}$.

For example, according to the lexical-grammatical features of the object in the sentence (or of the verbal syntagme) follows the passage of the verb from telic to non-telic:

- given object determined an undetermined quantity

[10] a) Ajo i lau rrobat // telic, risultative //

She washed the clothes.

b) Ajo lau rroba // non-telic, continuative //

She washed clothes.

- The object in its

entirety versus a part of

[11] a) Ajo e hëngri tortën // telic, risultative //

She ate the cake.

b) Ajo hëngri nga torta (një fetë) // non-telic, continuative //

She ate cake (a slice).

- also the presence of a complement in the predicate can transform a non-telic verb (and non-ergative) in telic (nonaccusative):

[12] a) Ajo vrapoi (në stadium) // non-telic, continuative, non-ergative //

She ran (in the stadium)

b) Ajo vrapoi drejt shkollës // telic, risultative, non-accusative //

She ran to school.

According to statements made to date, even through the Albanian language is given evidence in favor of the conclusions of many contemporary linguists, that the opposition telic/non-telic is primarily semantic-aspectual, highlighted not through the information received by one lexical enter but mainly through the requirements of all the predicate, where the meaning of the verb is only a part.

\section{BIBLIOGRAFY}

[1] AA.VV. (1997), Gramatika e gjuhës shqipe II, Tiranë, Akademia e Shkencave e Republikës së Shqipërisë, Instituti i Gjuhësisë dhe i Letërsisë.

[2] Alimhilli, Gj. (1995), Risultativi e trasformativi nell'albanese, Studi Italiani di Linguistica Teorica e Applicata XXIV/3, 557-565.

\footnotetext{
${ }^{1}$ Arad's work (1995: 215-220) helps us to observe these phenomena in Albanian about the projection of arguments, that is, how the arguments of a predicate in a syntactic structure are integrated. The author defends the point of view that only the enter of such verbs as to run, to eat etc. it is not fully qualified as unaccusative or as unergative, what determines whether they are unaccusatives or unergatives it is the syntactic structure within which you have these verbs. It is pointed out by her observations, as well as by other researchers (Van Valin (1990), Dowty (1991)), that the definition unaccusative / unergative is related to the semantic and aspectual quality: unaccusativity is accompanied by non-agentive, telic feature, while unergativity is accompanied with agentive, not telic.
} 
[3] Alimhilli, Gj. (1997), Veprimi foljor në gjuhën shqipe, Quaderni del Dipartimento di Linguistica 14, Università della Calabria, 105-113.

[4] Alimhilli, Gj. (1999), Mënyrat e veprimit foljor në gjuhën shqipe në lidhje me rrethanorin e kohës, Mandalà, M. (përgatiti) Studi in onore di Luigi Marlekaj, Bari, Adriatica Editrice, 27-46.

[5] Alimhilli, Gj.(2001), L'Aktionsart nella lingua albanese - L'azione verbale telica, Studi Italiani di Linguistica Teorica ed Applicata, n. 1/2001, 115-142.

[6] Alimhilli, Gj. (2001), L'Aktionsart nella lingua albanese - L'azione verbale continuativa e stativa, Studi Italiani di Linguistica Teorica ed Applicata, n. 2/2001, 371-395.

[7] Alimhilli, Gj. (2002), Mbi klasifikimin foljor të ashtuquajtur Aktionsart, Studi in onore di Antonino Guzzetta, Palermo, Helix Media Editore, 23-34.

[8] Alimhilli, Gj. (2003), I verbi telici nella lingua albanese, Cinque Secoli di Cultura Albanese in Sicilia, Atti del XXVIII Congresso Internazionale di Studi Albanesi, Palermo, 27-48.

[9] Alimhilli Prendushi, Gj. (2009), L'Aktionsart nella lingua albanese Klasifikimi foljor sipas

[10] mënyrave të veprimit në gjuhën shqipe, Falco Editore, 37-58.

[11] Alimhilli Prendushi, Gj. (2013), Nuovi sviluppi sull'azione verbale nella lingua albenese,

[12] Konferenca shkencore ndërkombëtare "Komunikimi ndëretnik në Ballkan", Universiteti i Tiranës -Fakulteti i Historisë dhe Fililogjisë, 161-169.

[13] Alonge, A. (1994), Sulla classificazione verbale cosiddetta "aspettuale": discussione di alcuni problemi, Archivio Glottologico Italiano LXXIX, 160-199.

[14] Arad, M. (1995), On the projection of ditransitive verbs, UCL Working Papers in Linguistics 7, University College London, 215-220.

[15] Demiraj, Sh. (1986), Gramatikë historike e gjuhës shqipe, Tiranë, 404-405.

[16] Dowty, D. R. (1991), Thematic Proto Roles and Argument Selection, Language 67, 547-619.

[17] Dhrimo, A. (1996), Aspekti dhe mënyrat e veprimit foljor në gjuhën shqipe, Tiranë, Shtëpia Botuese "Libri Universitar", 153-156 \& 260-265.

[18] Dhrimo, A. (2008), Çështje të sistemit foljor, Për shqipen dhe shqiptarët, Vëllimi I, INFBOTUES,

[19] Tiranë, 234-417.

[20] Floqi, S. (1958), Skicë e së folmes së Dangëllisë, BUSHT SSHSH, 113-116.

[21] Merlo, P. (1990), Risultative in italiano e in inglese, Rivista di Grammatica Generativa 14, f. 29-53.

[22] Van Valin, R. D. (1990), Semantic Parameters of Split Intransitivity, Language 66/2, 221-260.

[23] Croft, W. (2012), Verbs: Aspects causal structure, Oxford: Oxford University Press, 31-69,

[24] 127-171. 